Vukoman Jokanović ${ }^{1,2 *}$

${ }^{1}$ Institute of Nuclear Sciences Vinča, Belgrade, Serbia

${ }^{2}$ ALBOS Ltd, Innovative Company, Belgrade, Serbia
Review paper

ISSN 0351-9465, E-ISSN 2466-2585

UDC: $576.36: 28-187.3$

https://doi.org/10.5937/zasmat2102135J

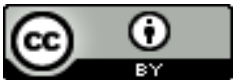

Zastita Materijala 62 (2)

$135-140$ (2021)

\title{
The short story of the miraculous daily resurrection of life in us
}

\begin{abstract}
The development of modern science in various fields today often exceeds the limits and ideas of the bravest philosophers and scientists of our time. And certainly the most intriguing areas of research are those based on the molecular basis of life processes. The complexity and complexity of the human body, countless intertwined feedback loops that regulate internal processes in the body and enable its survival, can best be interpreted at the micro and nano level, ie at the level of the cell and its subcellular structures. This opens up huge potentials for understanding and influencing living systems, but also unlimited challenges for science. The monograph "How cells live and die in us" is unique in many ways. The multidisciplinary procedure provides a comprehensive overview of the complexity of the human body, as well as its possible functioning at the cellular micro and nano level, ie at the level of molecules, atoms, nuclei, protons, etc. The story is inspired by Balasevic's line between the year of birth and the year of death.
\end{abstract}

Keywords: cell life, cell death, stem cells, brain, DNA, life eternity

\section{BASIC IMPRESSIONS}

When we do anything in life or write about anything, then we are no longer important. Our heroes are always much more important than us, to whom we give life with our words and as the creator of all things and existing creatures, living and non-living, we place him in a stage frame in which he should already look like a real living being, possessing a mind. , intention, desires and which, following our rhythms of the body, becomes our alter ego who, if the work is perfect, lives a stronger life than the creator himself. As a germ of eternal doubt, the dilemma always hovers over us, whence the need of these hidden worlds to give a voice about themselves through us, and unravel their deepest secrets, aware of the incredible disproportion of their power according to which our intelligence is like a walnut shell swimming on a huge sea waves. Even so, the best among us who are themselves comparable to the dust on the wings of a butterfly that flies and flies away to an unknown destination, sometimes given the incredible power of revelation.

\footnotetext{
${ }^{*}$ Corresponding author: Vukoman Jokanović

E-mail: vjokan@gmail.com

Paper received: 12. 02. 2021.

Paper accepted: 10. 03. 2021.

Paper is available on the website: www.idk.org.rs/journal
}

That feeling that something magical is being born, which flows unstoppably like a river and sparkles in us, while amazed by the perfections of nature and the genius of the human mind, we recognize all those incredible outlines of the unknown that sparkle like pearls, illuminating our ganglia inner strength and unrest, which erupted from that world which is being created and shaped. And this book, like all other books inspired by that flash of the mind, is just a clumsy attempt carried by hope and the awareness that maybe this is another unsuccessful assault on windmills and that Sisyphus' stone may reach the top of the hill before me, I head deep the uncertainty of the very heart of wisdom [1].

Alone and with deep faith that if I manage to catch the rhythm and become one with that divine flash of nature, aware that my senses need to be sharpened so much before that I can hear the whisper of ants like the roar of elephants, because only then will such inspiration to be powerful enough to connect the hills with the gaps between the gaps, to find in the labyrinth of limited knowledge a path in which life reflects itself, through which only then perhaps the whole story will flow and like a carpet full of patterns with thousands of intertwined knots to the sun as a magnificent building, which for so long had been visible only in the fog. As an echo in the brain over 
and over again, as in anyone who dares to cross a bridge as thin as a lock of hair between the rocks raised to the abyss, the question is so simple and so logical, how to testify to what is so predominant about ourselves, and what is so superior to any of our attempts to be on the slopes of the mountains behind which twilight is most beautiful, as we sink into the depths of our thoughts and observe that unrepeatable image of the reflection of light on the cloak of mist that makes the scenes of existence unrepeatable [1].

The very title of the book is enough to cut into our mind like a blade, disturbing the silence of our dormant brains, while like the blade of a still clumsily forged knife it cuts the worlds of incredible secrets, which eternally sparkle in us and are announced in countless ways every moment. we travel between worlds in complete darkness in the middle of a quantum pit and worlds of interference that ripple like snowdrifts on the surface of the ocean we are sinking into, breathless. Reading the book, I hope that the reader himself will from time to time feel as if he is passing through the most beautiful landscapes that are born of the pearls of the human mind, amazed as the author himself with his magnificent genius, which shows us plenty of incredible connections and analogies, testifying that from time to time, as if in the middle of our minds, Prometheus was resurrected from somewhere, chained to a rock and the fire that only he had the courage to steal from the gods, illuminates the sea of silence within ourselves in which incredible things happen. That is the starting point of the break. How to start from it? In which direction? What would be the first real word? A sentence? Thought? [1-4]

Knowing that I am wrong and that it is the only thing in which I have no rival, always striving for the impossible, ready to ride on the wildest waves and on the thinnest bark of balsa, a single question sparkles in me that can be summed up in just three words. What is life?

And the answer, the answer to such a simple and naive question as the one already given, obviously requires courage and perseverance and a heartbeat so strong that it depicts all the fears of a being that awakens all the senses, making the very thought of such a journey an unspeakable pleasure for a climber which hangs above the abyss on the thin rope that life means. Life and death are our everyday life, as we have known it for centuries. They alternate as day and night in an endless series. Every day, the day of new life and new hope, and every day, the day of death in us, in our cells, which in such an enigmatic and infinitely imaginative way, following their paths and choosing them again and again, expose themselves to very unusual destinies. As lovers infinitely in love with each other, death and life live in us at the same time. Parts of us die, while other parts renew themselves with thousands of different paths and destinies that those paths carry with them.

That mystery of life in which our particles, our cells are constantly dying, is like the taste of wine, because the cells are dying of some absurdity, just because, thanks to that, life goes on. Like every life of an adult, the life of every cell is unpredictable. And her destiny. Some choose death intentionally to survive me, because the whole point of life is that all currents follow one flow and that if there is hope for some part of us, and if that hope is conditioned by the death of another part of us, the cells always choose in the right way, boldly, death for the sake of life. Sometimes they do not recognize the danger, sometimes they are blind to everything similar to themselves and lead us to incurable diseases such as cancer. And so, thanks to that, through ourselves, but also through the destiny of all beings we are surrounded by, we see that the only thing is permanent transience. Flowers, synonymous with beauty, bloom, wither and die. Then a new flower appeared and continued the same sequence. The plant seems eternal to us. During that time lives and reproduces again. in the full splendor of beauty, waiting for its moment some new morning, when it will shine again adorned with a wealth of colors of new flowers. Water, oxygen, sunlight. Together, they give us life, from the tiniest creatures, cells and bacteria to highly developed organisms with millions of such cells that unite in special ways, giving tissues and organs. And that is the characteristic of all beings, be it bacteria, insects, worms, animals or humans. The microscopic cells in them show their infinite intelligence and wisdom, although they have a short lifespan that is sometimes only measured in hours.

The cells in us do not have the same destiny. So while some like neutrophils and basophils live only 6 hours to a few days, muscle cells live about 15 years. In addition, about $10 \%$ of our total skeleton is replaced every year, while the nerve cells that are the only ones living our entire century, sharing their fate with us, are not renewed, although we lose as many as 200,000 neurons every day in our adulthood. In addition, the cells of the intestinal mucosa divide throughout life, while the cells of the kidneys and lungs stop dividing, when the body is fully grown. Every minute, more than 200 million cells are created to replace old, dying cells. And that is what happens in us every day, while we figure out the meaning of our existence, so important to ourselves and so absurdly funny. 
And every part of us, every cell except red blood cells, we have no idea that it contains a complete DNA package, in which our entire destiny is packed, as a kind of internal software. And while we dream of how unique we are and how the whole world is just waiting for us, our body begins to change slowly and age and children whose cheeks burst with health wrinkles appear because our cells are replaced by cells that contain less water, giving the face the maturity of experience and like a knife the thought of how transient we are cuts into our hearts. Our enchanting beauty because of which they were left breathless, we feel now is just a swan song behind which there is always the eternal sorrow for youth. We imagine how nice it would be if our cells, as newborn cells, contained almost twice as much water, because then there would be no age wrinkles, which no "face-lift" can replace. Finally, imagine cells that are programmed to destroy themselves in the event of an infection or mutation [1].

Following the previous scenario, in time, which for some cells is measured in hours or days, they participate in incredible construction projects, give birth to new cells and train them with unimaginably complex rules of life, and then die immediately afterwards. One cell dies and the other is born and the breath of life is transferred to a new day. In every organ, at every moment, millions of cells die in us, so that the same numbers of new cells are born again. Our body is a battlefield where at any moment an innumerable bunch of different cells suffer in the most beautiful adventure of life. And for all those dead cells, we need to find a safe place and store them, before they are expelled from the body so that they do not kill us with their toxicity, during the inevitable disintegration. As in the lliad and the Odyssey, before us, at every step, an incredible image of cemeteries and cradles emerges. That same picture happens in each of our organs. Only balance matters. And as long as it exists, everything works flawlessly. And what follows from this? Each organ will obviously be replaced in a short time, with completely new cells, in a process that lasts our entire life.

The anatomical structures arising from the interweaving of cells show incredible forms, which, sanctified from within, appear in full splendor of beauty, especially some of them, such as the brain, with their uniqueness, which is incomparable to anything else, which is reflected in its incredible the ability to control the whole order of such a perfect work as the organism and to harmonize all the parts in it in an extremely harmonious way. After all this, the question of how old is who seems completely meaningless, because if almost everything in us can be measured by the age of the baby, or the child at the earliest age, then we are who knows how many times a newborn child. The organs that are renewed in us testify to that, and if every organ is many times younger than ourselves, and we are a set of organs, then we are also eternally young, aren't we? Cells are born and die to be. What a fascinating game. Like a mold in which nature reshapes us every day [1-3].

And not only our cells but also the functions that are part of their character, everything is reshaped: our breath and our thoughts, our mind and the world of emotions, beliefs and hopes, beliefs, superstitions. As on a big stage, where numerous paths and numerous destinies intersect, our body is constantly reborn. And now, when everything is already like that, when the body has always been and will always be new, how to explain where the disease came from? What makes us mortal? What is the cause, which makes us earthly, instead of being eternal as we have dreamed for centuries? Numerous thinkers at all times agree on one thing. The cause of the disease usually lies in us, our mind trapped by various prejudices, wrong upbringing, education, beliefs, and convictions. We are usually enemies of ourselves, because we do not allow endless possibilities of self-healing to blossom in us, in which our brain is always the first mediator, that grandiose construction, in whose depths I clumsily dived while writing one of the chapters of this book is based on the functioning of the visible and invisible physical world, traveled the intelligent paths of cells, finding values that make them eternally young and unchanging, and showed how cells slowly slide into disease and death, choosing unusual paths, sometimes conditioned by our bad habits or stress that is almost impossible to avoid.

Going back to that delicate balance, cell death and life, it is noticeable that the balance changes whenever more cells die than are born, which leads to organ shrinkage, or vice versa, fewer cells die than which is born, causing the organs to expand. In both cases, death follows. Only when cells die in a balanced way do we live. Death follows us even when the cells do not die. The point of life at the cellular level is the balance of death and birth. Death is very important, even necessary. It happens in us every moment, until in the end it definitely happens thus nullifying both life and death in us. It is like a big snowball that slides slowly down the hill, causing horror in our mental dreams. And every day of dying in us is a day in which, fleeing in thoughts from the graves of dead cells, we follow our earthly journeys, until our body also becomes dust. And our body? What's been going on with him all this time? Hair grows and new hair has already grown to such an extent that we 
have to cut it at least once in three months. And only nails? In a week, they should be shortened again. For five weeks, the old nail is not weeded. It has been replaced with a brand new nail. The cut on the finger heals in a few days. New skin covers the incision site. And our body is no longer in the same skin. These are all visible signs of change on the outside. And what happens inside? All becomes the same, exactly the same. After a short time, all organs were replaced with new ones. In six months, the bone has outgrown, and instead of a broken bone, the new bone is now as solid as a rock. Our body, like a wizard's workshop, during all that time we live, going crazy in a thousand ways, and not paying any attention to what is happening inside us, miraculously transforms everything we bring into it into exactly what it is most needed. It produces like wax a sticky scum in the corners of our eyes, strengthens tooth enamel, adjusts fingernails, produces complex acids, enzymes, bile for our stomachs, and super sensitive hormones for our explosive urges and often hot emotions [1].

Although we know nothing about what is happening and how it happens in such an ideal way, our body always creates it all over again, miraculously combining it with a skill that is incomparable to anything imaginable to us. It gives moisture to our lips and eyes, provides a continuous charge to the heart muscle to pump constantly and automatically redirects blood from one part of the body to another, always pushing it where it is most needed. It gives signals when to eat and drink and stop. When we need to sleep, get up, programmed as an autopilot while we rest and lie down completely unaware of it.

The nature around us supplies us with various ingredients needed by the body, fruits, vegetables, and other foods and gives us a thousand reasons to enjoy trees, flowers, nourishing our soul, which is so important for the balance between cells and life itself. Cows graze in meadows and produce milk, since when do we make butter, cheeses and much more that will undergo a fantastic transformation in our bodies and become our cells, organs, we [1,2].

Cells are constantly making decisions about what to do, where to go, and when to divide. Many of these decisions are made by the wisdom of our DNA, once strictly controlled by external signals and stimuli. Other decisions appear to be independent and autonomous made by individual cells. And all those numerous decisions that the cells make in an independent way at all times, follow a well-thought-out plan in advance, followed by an even more thoughtful outcome.

In the development of embryos, the most amazing thing is when stem cells make the decision, from a record known only to them, to embark on an adventure to start creating something unimaginably complex and perfect from almost nothing, differentiating according to an already precisely determined plan and so some of them they decide to become muscle, nerve, skin or bone cells. It is essential for the organism that everything takes place in harmonious proportions in order to develop into healthy human beings [1].

Researchers working on stem cells have discovered that by adding chemical signals to them, some of them, but not all of them, can be directed to turn into nerve cells. Only a small fraction of cells follow such instructions. It follows that since the chemical signal is not decisive, some other mechanisms must be involved in the process.

The ideal model for studying the behavior of stem cells is the organism dictyostelium (a special type of amoeba, which lives in the ground and transforms from a monocellular organism into a multicellular, shorter dicty). As with the human embryo, the life cycle of such cells includes differentiation, with them having only two choices: to survive or to die. It has been shown that such cells can also be transplanted into human cells, which gives us the opportunity to more successfully investigate the origin of the disease and the mode of the disease. At every moment within its life cycle, the more dicty cells die, the more exactly they re-emerge. It is not determined by any external factor or collective intelligence what decision each of the cells will make, whether they will die or live. In addition, there is no difference between cells that will live and cells that will die. All of them go through similar challenges, showing characteristics and appearance similar to stem cells, which is only at first glance completely random, because the basic pattern of events cannot be predicted in advance. Viewed from an evolutionary perspective, what does these cells or embryonic cells still lead to billions of seemingly independent decisions? Although it seems to us that there is no practical purpose in all this, it is obvious that some of them always make the decision to survive, transfer their genes and prolong the species, and others die. If such cells accumulate in layers in a multicellular organism, then some layers will be preoccupied with the creation of new cells, while cells in other layers will make the decision to die, because that only leads to the life of the whole organism $[1,4]$.

And, how we can describe cellular communication? It is crucial, because when a cell makes its choice, it releases chemical signals to inform its environment of its decision. It is part of the mechanism that establishes balance in the 
process of formation of new tissues and organs. Cell differentiation is controlled in the highest forms of life, including humans. If the first cells to differentiate send signals to inform other cells not to make the same choice, it could be the key to explaining why the embryo produces the right share of all the various types of cells that make up the body, helping to synchronize the body as a whole. This explanation, however, does not shed light on the reasons that lead the first cell to make the decision to become something else, quite specifically. How to understand all this at the genetic level? Although the decision of each cell is completely unpredictable, it still seems that the decision that refers to the whole plan of creating new life, is related to the action of several transitional indicators. Genes produce markers during expression that predict which decisions a cell will make. Such genes show expression even when the cell is developing normally. Apparently these genes prepare the cell to respond at a crucial moment where to go and what kind of cells and organs to differentiate.

All cells of the same species carry the same genes and thus markers. The question is, if so, why do these genes show expression only in some of these cells? Is it a periodic phenomenon? If not, then all the cells would show the expression of the gene at the same frequency, which would cause their synchronization. However, it is most likely that only a certain part of the cells show expression at a given moment. The switching on and off of certain genes, in order to control the output of thousands of cells that make individual decisions, seems to be part of cellular reality [1-3].

Finally, it is obvious that death is inevitable and that it will come for each of us one day, but even then, life will not completely fade from our bodies. As our lungs stop breathing, our heart stops beating, our mind stops thinking, when our body begins to cool down, long after the cessation of our vital functions, the small pockets of cells will still live for days and even weeks.

Scientists are now taking such cells from the scalp and meninges of human corpses and reprogramming them into stem cells. In other words, the dead also have living cells that can be transformed into any cell or tissue in our body. This is how new stem cell therapies are developed and shed light on various forms of mental disorder, such as schizophrenia or autism. Mature cells can become immature cells, so-called. pluripotent stem cells, which are able to become an integral part of any tissue and replace cells that have been destroyed by disease or injury. Such a process is also performed on fibroblasts taken from the skin of human corpses. Fibroblasts collected from corpses are reprogrammed into induced pluripotent stem cells, using growth factors associated with stem cell activity. Reprogrammed cells have the potential to develop into a number of cell types including neurons found in the brain and spinal cord. Scientists today are able to recultivate fibroblast cells from deceased people even two days after death, although the corpses were not frozen during that time. Researchers who collected cerebral cortex fibroblasts showed that they were more likely to be successfully reprogrammed than fibroblasts from all other parts of the body. Neurons derived from such fibroblasts can be compared to real neurons of the same person. This shows that the technique of transforming fibroblasts into neurons is quite reliable, while the results obtained from such research can serve as a guide in elucidating various disorders and disorders in the development of some extremely severe diseases such as Parkinson's $[1,2,5,6]$.

Finally, let's go back to the brain, to which a large part of this book is dedicated. Human consciousness has found a place within the nonlocal global process, which connects the entire universe, defying the laws of classical physics and observations from everyday life. We seem to be intimately and integrally connected within the same global process that actively creates the shape of the Universe, thus providing a completely new meaning of understanding life, which fully corresponds to the modern expression of interconnectedness within the "global village". This testifies that there really is a central organizational principle of action.

\section{CONCLUSION}

Such a view of the place of man in the universe is an important shift in the paradigm of existence. We are not just small, insignificant creatures in a constant meaningless struggle for survival in the Universe, because through our dynamically created consciousness, we actively participate in the essential global process that makes up the world around us. We are brains, with tied strings. This kind of worldview paradigm has a huge impact, which is almost unimaginable, in all aspects of human behavior from personal to social. Some visionaries are already talking about the renaissance of the human brain, at the dawn of the third wave of civilization, characterized by a remarkable decline in physical labor and a rapid rise in intellectual labor (brain labor), as the fruit of the second wave of the 300 years ago. 10,000 years ago. That is the latest wave that belongs to the so-called, "quantum man" ("homo quantum") [14]. 


\section{REFERENCES}

[1] V.Jokanovic (2013) How Our Cells Live and Die, Institute of Nuclear Sciences „Vinca“, Belgrade, Serbia.

[2] V.Jokanovic (2014) The Deep Scientific and Philosophic Approach to the Future Nanomedicine, Given on the Base of Author Introduction in the Monograph "Nanomedicine, the Greatest Challenge of the 21st Century", Drug Des 3:2.

[3] V.Jokanovic (2020) Smart healtcare in smart cities, In book: Towards Smart World: Homes to Cities Using Internet of Things, Edition: First edition, Chapter: 4. Publisher: Taylor and Francis Group, p.45-73.
[4] V.Jokanović, B.Jokanović (2021) Brain-computer interface: State of art, challenges and future, in the book Artificial Intelligence Technologies, Applications, and Challenges, (paper accepted), Chapter 27, Publisher: Taylor and Francis Group.

[5] Jokanovic $V$ (2016) Bridge between nanophysics and alternative medicine; A new energetic approach to the human cell treatment and their healing. Lambert House Publishing, Saarbrücken, Germany.

[6] A.Vitrac, I.Cloëz-Tayarani (2018) Induced pluripotent stem cells as a tool to study brain circuits in autismrelated disorders. Stem Cell Res Ther, 9, 226-239.

\section{IZVOD}

\section{PRIČA O ČUDESNOM SVAKODNEVNOM VASKRSENJU ŽIVOTA U NAMA}

Razvoj savremene nauke u različitim oblastima danas često prevazilazi granice $i$ ideje najhrabrijih filozofa i naučnika našeg doba. A sigurno najintrigantnija područja istraživanja su ona koja su bazirana na molekulskim osnovama životnih procesa. Složenost i kompleksnost ljudskog tela, bezbroj isprepletanih povratnih sprega koje regulišu unutrašnje procese u organizmu $i$ omogućavaju mu opstanak, najbolje se mogu tumačiti na mikro i nano nivou, odnosno na nivou ćelije $i$ njenih subćelijskih struktura. Time se otvaraju ogromni potencijali za razumevanje $i$ uticaj na žive sisteme, ali i neograničeni izazovi za nauku. Monografija "Kako žive i umiru ćelije u nama" je po mnogo čemu jedinstvena. Multidisciplinarnim postupkom napravljen je sveobuhvatni prikaz složenosti ljudskog tela, kao i njegovo moguće funkcionisanje na ćelijskom mikro i nano nivou, odnosno na nivou molekula, atoma, nukleusa, protona itd. Priča je inspirisana Balaševićevom crticom između godine rođenja i godine smrti.

Ključne reči: život ćelije, ćelijska smrt, matične ćelije, mozak, DNK, večnost života

Pregledni rad

Rad primljen: 12. 02. 2021

Rad prihvaćen: 10. 03. 2021.

Rad je dostupan na sajtu: www.idk.org.rs/casopis

(C) 2021 Authors. Published by Engineering Society for Corrosion. This article is an open access article distributed under the terms and conditions of the Creative Commons Attribution 4.0 International license (https://creativecommons.org/licenses/by/4.0/) 